\title{
Quantifying the propagule load associated with the construction of an Antarctic research station
}

\author{
JENNIFER E. LEE* and STEVEN L. CHOWN \\ Centre for Invasion Biology, Department of Botany and Zoology, Stellenbosch University, Private Bag X1, Matieland 7602, South Africa \\ *jlee@sun.ac.za
}

\begin{abstract}
Although the impacts of biological invasions are widely appreciated, a bias exists in research effort to post dispersal processes because of the difficulties of measuring propagule pressure. Here we quantify the propagule pressure associated with the construction of a research station in Antarctica. Based on quantitative assessment of different classes of cargo, we predict that over 5000 seeds will be entrained during the period of building the station. Seeds from 34 taxa were identified, including known invasive species.
\end{abstract}

Received 27 February 2009, accepted 8 April 2009

Key words: dispersal, invasion, Halley VI, propagule pressure, risk assessment, vector

\section{Introduction}

Biological invasions constitute one of the primary concerns for the conservation of Antarctica and its surrounding islands (Frenot et al. 2005). Although non-indigenous species are not as extensively established on the Antarctic continent as they are on the surrounding islands, they have become one of the foremost concerns of the Antarctic Treaty's Committee for Environmental Protection (CEP), which is responsible for advice on the governance of the area south of $60^{\circ} \mathrm{S}$. The CEP has recognized the prevention of the introduction of non-indigenous species as the most effective step in preventing biological invasions (Mansfield \& Gilbert 2008).

However, research concerning invasion processes in the Antarctic is as much biased to post-dispersal processes and impacts as it is elsewhere (compare Frenot et al. 2005 with Puth \& Post 2005). Only a few studies have documented the relationship between the likelihood of introduction and vector numbers (Chown et al. 1998), the nature of microbial entry pathways (e.g. Hughes 2003), the role of ballast water and hull fouling (e.g. Lewis et al. 2003, Lee \& Chown 2007), and the relative significance of transport methods for terrestrial propagules (Whinam et al. 2005). In addition, although several of these studies highlight introduction pathways, they do not quantify propagule pressure in a manner that enables further explicit assessment of risk. Because initial dispersal is the stage in the invasion process on which all others depend, and because propagule pressure is such a significant correlate of introduction and subsequent invasion success (Lockwood et al. 2005, Richardson \& Pyšek 2006), its quantification is essential for understanding colonization pathways and how they might be managed to reduce the risk of introductions. Such quantification can provide insights readily applicable to a variety of situations (Puth \& Post 2005).
Although not every entrained propagule will be viable, and not every viable propagule will be able to overcome the abiotic barriers to establishment in the Antarctic, a proportion of all arriving propagules are clearly capable of overcoming these challenges (Frenot et al. 2005). The majority of established aliens in the region are restricted to the Southern Ocean islands (Frenot et al. 2005), where in some cases the number of introduced species exceeds the number of native species (Gaston et al. 2003). However, even in the harsh climate south of $60^{\circ} \mathrm{S}$ some species have successfully established (see Smith 1996 for a chronology of experimental and accidental introductions into the field and their success rate). More recently, Poa trivialis L. has survived for several years near the Japanese Syowa station and produced flowers (although the pollen was not viable) and Poа annua L. increased in abundance around the Polish Arctowski station (Chwedorzewska 2008). Whilst the total number of established aliens in the Antarctic is still relatively small, increases in visitor numbers to the continent (Naveen et al. 2001) and rapid climate change (Turner et al. 2007) places Antarctica under a rapidly growing threat of invasion. If the continent is not to meet the same fate as the surrounding islands, identification of introduction pathways and development of effective mitigation measures is essential.

Non-indigenous terrestrial species can enter the Antarctic via cargo operations, construction materials, food, and personal clothing and equipment. Of these, large-scale cargo operations are thought to be amongst the most effective vectors (Whinam et al. 2005), and several invasions of islands in the region have been attributed to propagule transport with building materials (Bergstrom \& Smith 1990, Frenot et al. 2001, Slabber \& Chown 2002, Jones et al. 2003). Moreover, large quantities of cargo and packing materials are shipped into the Antarctic each year to build and maintain research facilities. Indeed, at present, 


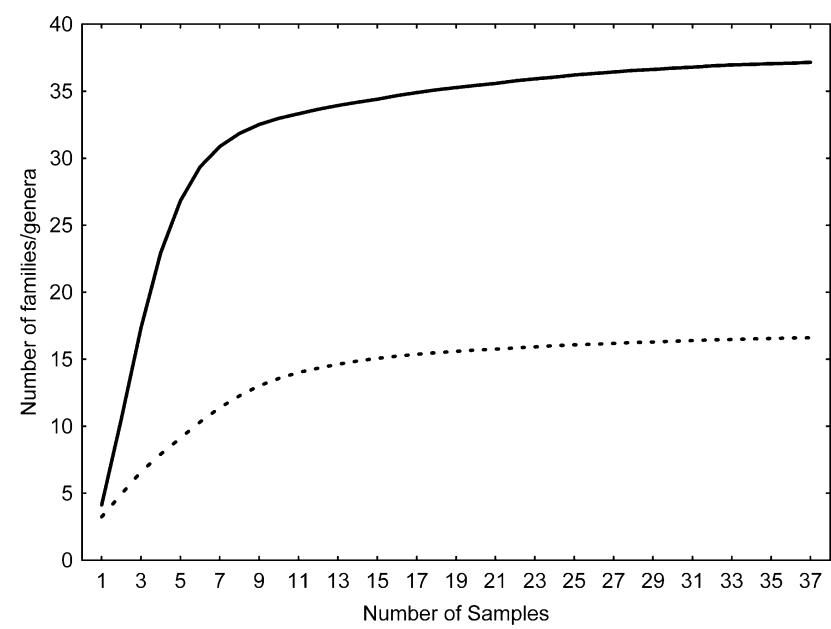

Fig. 1. Sample-based rarefaction curves showing the increase in numbers of families (dashed line) and genera (solid line) with increasing number of samples.

many nations are replacing or erecting new stations on or around the Antarctic continent or have just done so, viz. Atka Bay (Germany), Utsteinen Nunatak (Belgium), Halley Bay (UK), Schirmacher Oasis (India), South Pole (USA), and Dome A (European consortium). At present, 37 yearround and 16 summer-only stations operate in the region (http://www.comnap.aq/), all of which require upkeep.

Here we use the construction of the Halley VI station on the Brunt Ice shelf, Dronning Maud Land, to provide the first estimate of the propagule pressure associated with the construction of a typical Antarctic research station. The Halley VI construction (see www.antarctica.ac.uk) is ideal for this question because a variety of construction materials are sourced and stored in different locations, enabling comparisons to be made between cargo types and localities.

\section{Material and methods}

It is expected that $16000 \mathrm{~m}^{3}$ of materials will be required to construct Halley VI. In December 2007, c. $6400 \mathrm{~m}^{3}$ of that cargo was shipped from South Africa to Antarctica. Prior to shipment, it was assembled in Cape Town, and stored either at the dockside, which was bordered by waste ground containing weedy vegetation, or in a warehouse close $(10 \mathrm{~km})$ to the docks, located in a small industrial estate with no substantial propagule sources close by.

Major structural items were manufactured in South Africa, whereas internal fixtures and fittings were shipped from the UK and other parts of Europe. In total, $865 \mathrm{~m}^{3}$ of cargo comprising 92 individual units ranging in volume from $0.2-27.5 \mathrm{~m}^{3}$ was sampled. Although the range of cargo sampled at each location was similar, because of space constraints at the warehouse the majority of large volume items were stored at the dockside. Cargo was divided into materials packed in wooden shipping cases
Table I. Summary of families and genera found in cargo and the number of species in each genus that is listed on the Global Invasive Species Database (GISP). Percentage of the total propagule load that was found in samples collected from cargo at the dockside and samples collected from cargo at the warehouse is also listed.

\begin{tabular}{|c|c|c|c|c|}
\hline Family & Genera & GISP & Dockside & Warehouse \\
\hline Amaranthaceae & Amaranthus & 0 & 1.14 & \\
\hline \multirow[t]{9}{*}{ Asteraceae } & Arctotheca & 0 & 1.14 & \\
\hline & Conyza & 0 & 5.12 & 2.84 \\
\hline & Galinsoga & 0 & 4.55 & \\
\hline & Hypochoeris & 0 & 1.70 & \\
\hline & Inua & 0 & 1.70 & \\
\hline & Pseudognaphalium & 0 & 2.84 & 5.11 \\
\hline & Senecio & 1 & 2.84 & \\
\hline & Taraxacum & 1 & 3.98 & \\
\hline & Xanthium & 1 & 1.14 & \\
\hline \multirow[t]{2}{*}{ Brassicaceae } & Capsella & 0 & & 1.77 \\
\hline & Lepidium & 1 & 3.97 & 0.57 \\
\hline \multirow[t]{2}{*}{ Caryophyllaceae } & Stellaria & 2 & & 1.14 \\
\hline & Spergula & 0 & & 0.57 \\
\hline Chenopodiaceae & Chenopodium & 0 & 1.14 & 0.57 \\
\hline Cyperaceae & Cyperus & 0 & 2.84 & \\
\hline \multirow[t]{2}{*}{ Fabaceae } & Melilotus & 1 & & 1.14 \\
\hline & Vica & 0 & 2.84 & \\
\hline Malvaceae & Malvastrum & 0 & 2.27 & \\
\hline Oxalidaceae & Oxalis & 0 & 0.57 & \\
\hline Papaveraceae & Papaver & 0 & & 1.70 \\
\hline Plantaginaceae & Plantago & 0 & 3.98 & \\
\hline \multirow[t]{10}{*}{ Poaceae } & Agrostis & 1 & 5.68 & \\
\hline & Briza & 0 & & 0.57 \\
\hline & Bromus & 3 & 1.70 & \\
\hline & Chloris & 0 & 0.57 & \\
\hline & Dactylon & 0 & 3.98 & \\
\hline & Digitara & 0 & 2.27 & \\
\hline & Hordeum & 0 & 7.39 & \\
\hline & Lolium & 0 & 2.27 & \\
\hline & Poa & 2 & 3.98 & 1.70 \\
\hline & Sorghum & 1 & 1.14 & \\
\hline Polygonaceae & Rumex & 2 & 4.55 & \\
\hline Scrophulaceae & Striga & 1 & 3.41 & \\
\hline
\end{tabular}

$(n=56)$, materials packed onto pallets $(n=26)$, and loose material stored inside shipping containers $(n=10)$.

Cargo was visually examined and small seeds and larger clumps of vegetative material were collected using tweezers. A hand held vacuum cleaner (Black and Decker V2405) fitted with a mesh filter was used to gather fine material. Samples were stored in the dark at room temperature $\left(c .23^{\circ} \mathrm{C}\right)$. Invertebrate fragments, organic material and plant parts were found in the samples. Although the organic material probably contained microorganisms and some plant fragments may have been capable of vegetative growth, they could not be identified and were excluded. Thus, only seeds were considered: a reasonable first step given the significance of vascular plants as invasives in the region (Frenot et al. 2005). All seeds were identified to genus level. To determine whether sampling had gone to completion, non-parametric Chao 2 estimators were calculated using EstimateS (v8.0) and rarefaction curves were constructed for genus- and familylevel data (Gotelli \& Colwell 2001). 


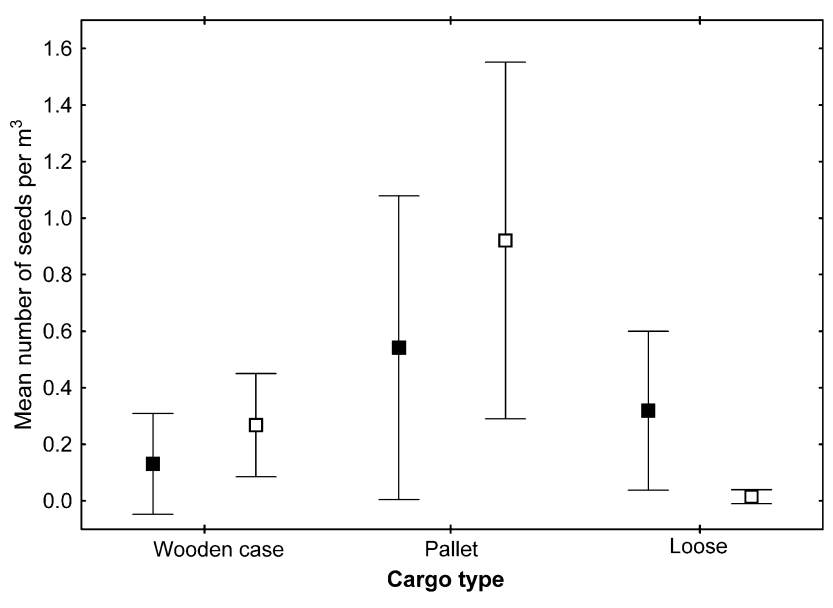

Fig. 2. Mean ( \pm s.e.) numbers of seeds per cubic metre for cargo types stored at the dockside (open symbol) and the warehouse (closed symbol).

A generalized linear model assuming a Poisson distribution and using a log-link function (SAS 9.1, SAS Institute Inc, USA) was implemented to compare the number of propagules in different types of cargo and cargo which had been stored in the different locations, while correcting for cargo volume. To compare the taxonomic composition of propagules from different shipping routes and cargo types, data were square root transformed, BrayCurtis similarities calculated, and a two-way Analysis of Similarity (ANOSIM) conducted in Primer (5.1.2 Plymouth Marine Laboratory) to determine significance of the differences between cargo types and storage locations. Thereafter, mean number of seeds per cubic metre was calculated for each cargo type and sampling location and scaled up to give an approximate number of propagules transported for the construction of the entire station.

\section{Results}

Sampling was approximately complete (Fig. 1) and 176 seeds representing 14 families and 34 genera were collected (Table I). Mean propagule load across all items was 0.31 seeds $\mathrm{m}^{-3}$ (SD 0.67). Asteraceae (32.1\%) and Poaceae $(30.4 \%)$ were most commonly represented. Dockside cargo had significantly higher propagule loads than warehouse cargo $\left(\chi^{2}=36.30, \mathrm{df}=1, P<0.001\right)$. Cargo packed on pallets had significantly higher propagule loads than loose items or those stored in wooden cases $\left(\chi^{2}=16.04, \mathrm{df}=2\right.$, $P<0.001$ ) (Fig. 2). Taxonomic composition of dockside cargo was significantly different to cargo sampled at the warehouse at family (ANOSIM global test $\mathrm{R}=0.31$, $P<0.001$ ) and at genus (ANOSIM global test $\mathrm{R}=0.087$, $P<0.003)$ level. However, samples from different cargo types could not be differentiated by composition at either the family (ANOSIM global test $\mathrm{R}=0.043, P=0.19$ ) or genus levels (ANOSIM global test $\mathrm{R}=0.006, P=0.57$ ).

Based on the proportion of each cargo type at each sampling location and using the mean number of seeds per cubic metre for each cargo category, the total propagule load of the cargo was estimated as 2203 seeds for the 2007/ 2008 season (Table II). It is expected that a further $9400 \mathrm{~m}^{3}$ of cargo will be required to complete construction. Assuming cargo composition similar to that found here, a further 3217 seeds will be entrained, bringing the estimated total to 5423 for the construction of Halley VI.

Table II. Volumes and predicted numbers of seeds for each cargo type stored at dockside and warehouse locations (Photographs B. Newham).

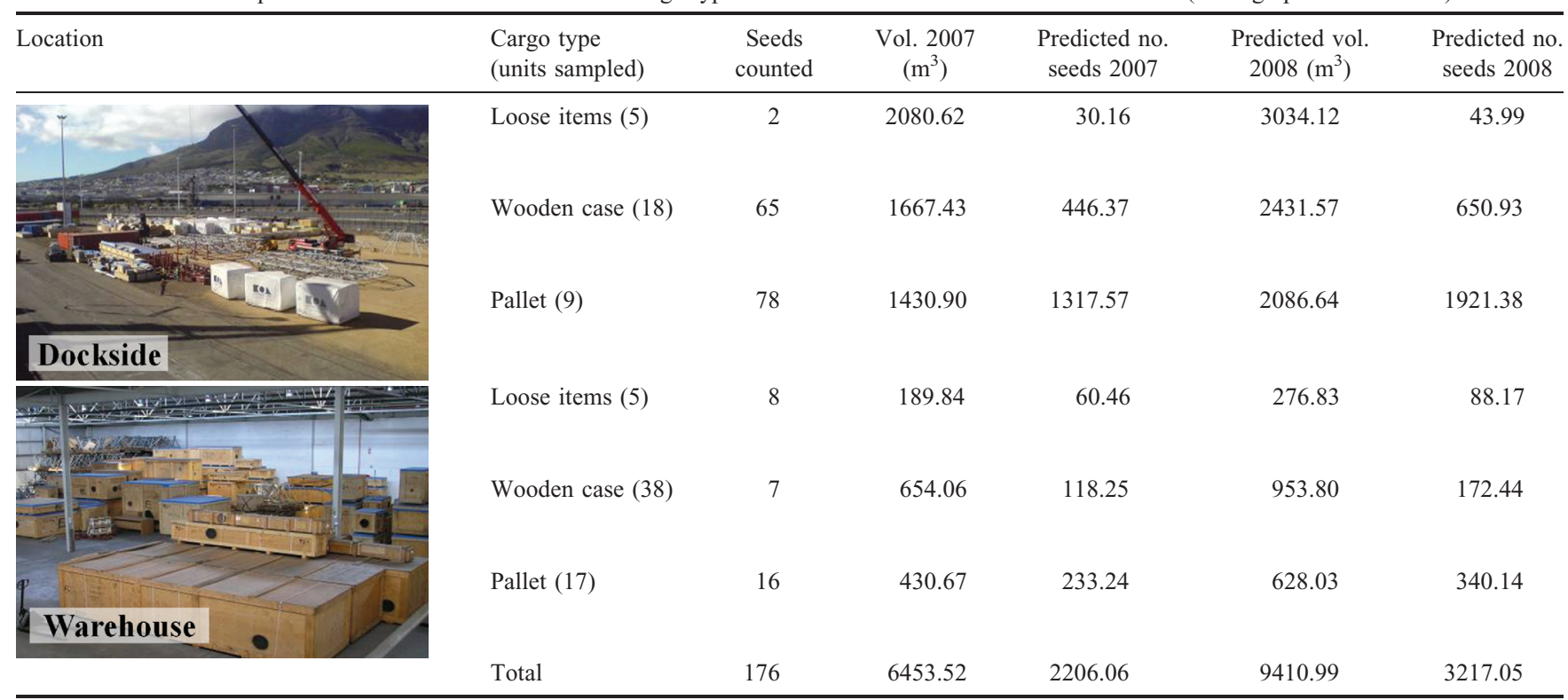




\section{Discussion}

Although no plant or animal could establish on the ice shelf at Halley VI, it is clear that the construction of an Antarctic research station, many of which are located on ice free ground (http://www.comnap.aq/), is likely to introduce substantial numbers of propagules in to the region. Experimental work on seed drop-off rates for standard cargo shipped to Antarctica indicates that c. $30 \%$ of these seeds drop off between the home port and the station, and a further $50 \%$ in the station area (Lee \& Chown in press).

A high proportion of seeds found in cargo were from taxa that include globally invasive species (Table I) and the two most commonly found groups found in samples, Asteraceae and Poaceae, both contain substantial numbers of species known to be invasive in the Antarctic region (Frenot et al. 2005, Chwedorzewska 2008). The prevalence of common alien taxa in the propagule load lends support to the idea of a self-sustaining cycle, and illustrates how invaders can undergo rapid increases in range size, with species that are common in disturbed areas, such as docksides, becoming entrained in cargo and then transported to other similar locations where they are likely to again become entrained (Shimono \& Konuma 2008). On a global scale, such entrainment has important implications for biosecurity policy, but is also important in an Antarctic context because of the practice of using central storage depots with satellite operations to remote field sites. On subAntarctic islands, such central storage areas often have a high prevalence of alien species (Bergstrom \& Smith 1990) and if these become entrained within cargo, resupply of field stations may facilitate dispersal to inaccessible areas.

While tourist and scientific cruises represent a high proportion of the total traffic in the Antarctic region compared with voyages dedicated to construction (Lamers et al. 2008), the latter are potentially problematic because of the volume of cargo involved and the difficulty of reducing its propagule load (Whinam et al. 2005). In consequence, and as we have shown, cargo for construction represents a major vector for non-indigenous species. This is especially concerning given much station building activity in the region (see above and http://cep.ats.aq/cep/ index.shtm) and ongoing climatic change at some sites (Chown \& Convey 2007). Moreover, the propagule loads documented here also suggest that cargo shipping globally may be a major vector of weedy species. All of the species found entrained in dockside cargo were found growing in the waste ground area of the docks and it thus appears that the propagules were locally sourced. If propagule loads on cargo bound for other ports is anywhere close to what we have found, the global propagule load is likely to be substantial. Here we found 176 seeds on $865 \mathrm{~m}^{3}$ of cargo for one voyage, while at the port of Cape Town alone 3400 vessels and c. 48770000 gross tonnes of cargo were handled in 2006 (http://www.ports.co.za/cape-town.php).
Nonetheless, management action to reduce propagule transfer can be taken, by selecting carefully the type of packing approach adopted, and more importantly, by making sure that wherever possible closed warehousing is used and docksides remain free of weedy species. Such approaches will be especially significant for shipping en route to and among sites on the Antarctic Peninsula, which, from a temperate invasive species perspective, is showing rapid climatic amelioration.

\section{Acknowledgements}

The British Antarctic Survey provided access to cargo, Brian Newham (Morrison Construction) provided information on cargo and shipping, and members of IPY Aliens in Antarctica offered helpful suggestions. Justine Shaw and two anonymous reviewers provided helpful comments on a previous version of the ms.

\section{References}

Bergstrom, D.M. \& Smith, V.R. 1990. Alien vascular flora of Marion and Prince Edwards Islands: new species, present distribution and status. Antarctic Science, 2, 301-308.

Chown, S.L. \& Convey, P. 2007. Spatial and temporal variability across life's hierarchies in the terrestrial Antarctic. Philosophical Transactions of the Royal Society of London, B362, 2307-2331.

Chown, S.L., Gremmen, N.J.M. \& Gaston, K.J. 1998. Ecological biogeography of Southern Ocean islands: species-area relationships, human impacts, and conservation. American Naturalist, 152, 562-575.

Chwedorzewska, K.J. 2008. Poa annua L. in Antarctic: searching for the source of introduction. Polar Biology, 31, 263-268.

Frenot, Y., Gloaguen, J.C., Masse, L. \& Lebouvier, M. 2001. Human activities, ecosystem disturbance and plant invasions in subantarctic Crozet, Kerguelen and Amsterdam islands. Biological Conservation, $101,33-50$.

Frenot, Y., Chown, S.L., Whinam, J., Selkirk, P.M., Convey, P., Skotnicki, M. \& Bergstrom, D.M. 2005. Biological invasions in the Antarctic: extent, impacts and implications. Biology Reviews, 80, 45-72.

Gaston, K.J., Jones, A.J., Hänel, C. \& Chown, S.L. 2003. Rates of species introduction to a remote oceanic island. Proceedings of the Royal Society of London, B270, 1091-1098.

Gotelli, N.J. \& Colwell, R.K. 2001. Quantifying biodiversity: procedures and pitfalls in the measurement and comparison of species richness. Ecology Letters, 4, 379-391.

Hughes, K.A. 2003. Aerial dispersal and survival of sewage-derived faecal coliforms in Antarctica. Atmospheric Environment, 37, $3147-3155$.

Jones, A.G., Chown, S.L. \& Gaston, K.J. 2003. Introduced house mice as a conservation concern on Gough Island. Biodiversity and Conservation, 12, 2107-2119.

Lamers, M., Hahe, D. \& Amelung, B. 2008. Facing the elements: analysing trends in Antarctic tourism. Tourism Review, 63, 15-27.

LeE, J.E. \& Chown, S.L. 2007. Mytilus on the move: transport of an invasive bivalve to the Antarctic. Marine Ecology Progress Series, 339, 307-310.

Lee, J.E. \& Chown, S.L. In press. Breaching the dispersal barrier to invasion: quantification and management. Ecological Applications.

Lewis, P.N., Hewitt, C.L., Riddle, M. \& McMinn, A. 2003. Marine introductions in the Southern Ocean: an unrecognised hazard to biodiversity. Marine Pollution Bulletin, 46, 213-223. 
Lockwood, J.L., Cassey, P. \& Blackburn, T.M. 2005. The role of propagule pressure in explaining species invasions. Trends in Ecology and Evolution, 20, 223-228.

Mansfield, B. \& Gilbert, N. 2008. Availability and applicability of legal tools for managing non-native species. In Rogan-FinNemore M., ed. Non-native species in the Antarctic: proceedings. Christchurch: Gateway Antarctica Special Publication, 131-164.

Naveen, R., Forrest, S.C., Dagit, R.G., Blight, L.K., Trivelpiece, W.Z. \& Trivelpiece, S.G. 2001. Zodiac landings by tourist ships in the Antarctic Peninsula region, 1989-99. Polar Record, 37, 121-132.

Puth, L.M. \& Post, D.M. 2005. Studying invasion: have we missed the boat? Ecology Letters, 8, 715-721.

Richardson, D.M. \& PYšEK, P. 2006. Plant invasions: merging the concepts of species invasiveness and community invasibility. Progress in Physical Geography, 30, 409-431.
Shimono, Y. \& Konuma, A. 2008. Effects of human-mediated processes on weed species composition in internationally traded grain commodities. Weed Research, 48, 10-18.

Slabber, S. \& Chown, S.L. 2002. The first record of a terrestrial crustacean, Porcellio scaber (Isopoda, Porcellionidae), from subAntarctic Marion Island. Polar Biology, 25, 855-858.

SмITH, R.I.L. 1996. Introduced plants in Antarctica: potential impacts and conservation issues. Biological Conservation, 76, $135-146$.

Turner, J., Overland, J.E. \& Walsh, J.E. 2007. An Arctic and Antarctic perspective on recent climate change. International Journal of Climatology, 27, 277-293.

Whinam, J., Chilcott, N. \& Bergstrom, D.M. 2005. Subantarctic hitchhikers: expeditioners as vectors for the introduction of alien organisms. Biological Conservation, 121, 207-219. 